\title{
Factors explaining the rating of Microfinance Institutions
}

\author{
Begoña Gutiérrez Nieto* \\ Department of Accounting and Finance \\ University of Saragossa, Spain \\ bgn@unizar.es \\ Carlos Serrano Cinca \\ Department of Accounting and Finance \\ University of Saragossa, Spain \\ http.//ciberconta.unizar.es/charles.htm \\ serrano@unizar.es
}

\begin{abstract}
The growing relevance of Microfinance Institutions (MFIs) has provoked the development of specialized MFI rating agencies that perform global risk assessments. In this paper we have conjectured different hypotheses pertaining to the relationship between financial indicators and the rating assigned. The hypotheses have been empirically tested, using MFIs accounting information and ratings from a leading agency. As expected, the larger, the more profitable, the more productive, and the less risky, achieved the better rating. This proves the usefulness of MFIs ratings for providers of funds. There is no observed relationship between social performance and rating. Given the social aim of MFIs, it is necessary to encourage rating agencies to engage in the development of social ratings. These social ratings should complement financial ratings, giving information about the accomplishment degree of the MFI social goals.
\end{abstract}

JEL Classification: G290

Keywords: Microfinance Institutions (MFIs), Microcredit, Rating, Social Performance, Accounting Ratios

\footnotetext{
- Acknowledgements: The work reported in this paper was supported by grant SEJ2004-04748/ECON of the Spanish Ministry of Education and Science, and the European Regional Development Fund (ERDF) under the title "Management Efficiency of the Socially Responsible Investment organizations".

* Corresponding author. Gran Vía 2, 50005 Zaragoza, Spain. Telephone: +34 976 761791. Fax number: +34 976761769
} 


\section{Introduction}

Microfinance Institutions (MFIs) are not a rarity any more, but are becoming first class members of financial and banking systems, at least in developing countries. Their growth parameters are outstanding, both in the number of entities and in the number of clients. According to Daley-Harris (2005), as of December 2004, 3,164 microcredit institutions have reported reaching 92.3 million clients. The growth from 54.8 million poorest clients at the end of 2003 to 66.6 million poorest clients at the end of 2004 represents a 21.6 percent growth annual rate. The focus of MFIs in social matters appears to be their main attraction. Many of their borrowers are socially excluded, and they lack access to conventional credit systems. Although MFIs can obtain funds from financial markets, funds from donors or socially responsible investors are widespread. These providers of funds not only aim at economic return but also at social return. Donors and investors want to know how well their money is being managed. This has stirred the recent development of MFI rating agencies. MFIs have to submit themselves to performance assessments taking into account their dual nature: financial and social. Is it possible to aim at so different goals like being profitable and lending to the poor? What aspects matter to develop a MFI rating? In this paper we analyze the rating assessments received by MFIs. The relationship between rating and financial performance is studied using accounting information. The relationship between rating and MFIs social performance is also analyzed.

Industrial corporate bonds rating exist since the early 1900s, see Levich et al (2002) for a literature review. Nowadays it is a blooming industry, led by centenary rating firms, such as Standard \& Poor's, Moody's, and Fitch. By contrast, MFI ratings are fairly new, since first evaluations were made in 1996. There are two kinds of institutions that perform this task: conventional rating firms and specialized microfinance rating companies. But, according to Jansson (2003), the first are starting to work with microfinance, and the second lack recognition among investors.

The CGAP (Consultative Group to Assist the Poorest), and the IADB (Inter-American Development Bank), created in 2001 the Microfinance Rating and Assessment Fund (Rating Fund). Rating Fund is a marketplace for rating agencies and MFIs. The providers of rating services carry out credit ratings or global risk assessments. According to Rating Fund, a credit rating is "an opinion of the ability and willingness to pay a specific debt obligation on time; it measures creditworthiness and always has a grade". Regarding MFIs credit ratings, the number is an anecdote; the pioneer local issue was launched in 2002 by Compartamos, a Mexican MFI. 
Global risk assessments are quantitatively more important. They are defined by Rating Fund as "an opinion of the ability to deliver according to objectives". In our days, 13 MFIs rating agencies perform every year around 150 global risk assessments.

The assessment obtained from rating agencies is a matter of interest for funding sources, donors or investors, but their expectations can differ. It seems that investors prefer sustainability to outreach. The opposite would be true for donors since they prefer impact to sustainability. Thus, investors would prefer a financial strength based rating assessment and donors a social centered one. The well known debate about the role of MFIs is manifested here: institutionists versus welfarists; Yaron (1994), Conning (1999), Woller et al. (1999).

Institutionists prefer financial self-sufficiency and sustainability. Their argument is that a sustainable MFI will survive with its own revenues, without the help of external donors; Adams and Von Pischke (1992). Welfarists say that MFIs role is to help the poor; and that sustainability should be a secondary issue; Hulme and Mosley (1996). For some eclectics, both visions can co-exist; Morduch (2000).

In this paper a series of hypotheses are discussed. It would be expected that the MFIs with better financial performance would receive the better ratings. Hypothesis on the relationship between social performance and rating are also suggested: that will become a source of further debate.

The hypotheses are empirically tested with a sample of MFIs. The rating industry is scattered: there are many agencies using different methodologies. For that reason we have concentrated our empirical research on global risk assessments from only one firm, Planet Rating, a leading rating company specialized in MFIs. We analyzed MFIs accounting information extracted from publicly available annual statements. A series of financial ratios have been calculated. Information on social performance is more difficult to obtain, and this kind of indicators are not as widespread as financial ones. But several measures related to outreach were collected. An example is the percentage of borrowers below the poverty line.

The next section of this paper makes a literature review on rating and MFIs. This is followed by a hypotheses section discussing the relationship between rating and financial and social performance. It is followed by an empirical section which details the research methodology and the sample data. Hypotheses are tested and results obtained. The paper ends with a conclusions section. 


\section{Microfinance institutions (MFIs) and rating}

In this section we will do a literature revision on MFIs financial performance, concentrating on rating issues. Secondly, we will review the literature on social assessments.

\subsection{Financial performance and rating}

MFIs give small loans, microcredits, to low income people excluded from conventional financial institutions. The Grameen Bank from Bangladesh, considered the pioneer MFI, was established in the late 70's; Lindenberg (2001). Even though this bank has its origin in Bangladesh, it promotes today microfinance programs in many other countries.

Financial information issued by MFIs has traditionally been scarce and poorly standardized. As the sector matures, the need for an efficient use of resources grows. The same can be said about the transparency in their management. But not every MFI is willing to release its financial data, specially the less efficient ones, or those that have difficulty meeting reporting standards. Better transparency would improve funding allocation, introducing a mechanism to select efficient MFIs (Tucker, 2001).

If MFIs industry is young, MFIs rating agencies are even younger. Thirteen agencies have been identified in performing MFI rating: Apoyo \& Asociados, Accion Internacional, Classrating, Equilibrium, Feller rate, Fitch rating, Planet Rating, M-CRIL, JCR-VIS, Microfinanza, Microrate, CRISIL, and Pacific Credit Rating. Table 1 shows a brief description of each rating, excerpted from their own web pages. Some agencies utilize rating methodologies based on the leading firms in the rating sector. For example, Feller Rate is Standard \& Poor's strategic alliance partner in its country, Chile. Some others have chosen to establish their own methodologies. An example is JCR-VIS, which has developed the MIRACLES method, acronym for Management, Information systems, Reputation, Asset quality, Capital, Liquidity, Earnings and Supervisory systems.

*************

Table 1 about here

************** 
Table 1 reveals that different rating agencies use different scales. They are difficult to compare, because those using the same grades not always assign the same meaning to the grades. The scales are very different, with their own definitions, and this way it is difficult to relate the scores assigned to MFIs by several raters.

Empirical research on accounting and finance has analyzed ratings from different points of view. Rating agencies claim that they do not only examine financial statements, but that they also use qualitative information. Pioneer works from Horrigan (1966), Pogue and Soldofsky (1969), Pinches and Mingo (1973), and Kaplan and Urwitz (1979) investigated the determinants of bond ratings. They specially studied the usefulness of financial information for predicting ratings. They perform several statistical multivariate techniques to study the relationship between accounting information and the rating assigned.

Most recent works in this field concentrate on more specific issues of the rating process. Poon (2003) finds that unsolicited ratings present worse assessments than solicited ones. Morgan (2002) examines the banks' opacity from the lack of consensus among main rating agencies.

Another related line of research studies the rating of financial institutions in developing countries. Ferri et al. (2001) examine the behavior of issuer ratings in developing countries, and find that bank and corporate ratings appear to be strongly related in an asymmetric way with changes in sovereign ratings. Bongini et al. (2002) study the power of credit ratings to predict bank insolvency in these countries.

Academic research analyzing financial information issued from MFIs is still scarce. Gutiérrez-Nieto et al. (2006) studied financial efficiency from a sample of Latin-American MFIs, using the Data Envelopment Analysis technique. An overall ranking of MFIs was obtained in terms of how they make use of inputs and outputs. Such efficiency rankings can be used by MFIs to highlight their reliability to potential funds suppliers. One of the seminal studies using empirical data of MFIs rating is Hartarska (2005). She finds that external governance mechanisms such as auditing, rating, and regulation, have a limited impact on outreach and sustainability of microfinance institutions. More research and better data is needed to ensure that strong organizations direct scarce resources to the entrepreneurial poor. 


\subsection{Social assessment}

Let us think about this in social terms. We have found that three issues can be brought up for discussion: the assessment of social performance in banking, the assessment of social performance in NGOs, and the development of specific methodologies to measure MFIs social impact. This will be the matter of our next discussion.

Since 1997, US banks have to submit themselves to an evaluation in terms of their compliance of the Community Reinvestment Act (CRA). They have to meet "the credit needs of local communities in which they are chartered". See, for example, Johnson and Sarkar (1996) or Bostic and Robinson (2004). Prior to eventual expansion, the bank has to receive approval on its performance accomplishing CRA guidelines. Ratings take the following categories: Outstanding, Satisfactory, Needs to Improve, and Substantial Non-compliance. This is very much in line with Corporate Social Responsibility ideas, which have their roots in Triple Bottom Line reporting models. Companies have to report their performance on economic, social and environmental matters. If this is true for all kind of firms, we think that it will be even truer for MFIs.

Many MFIs adopt the organizational form of NGO. Manne (1999) proposed that ratings serve as control mechanisms of NGOs. An external firm should measure the social aspects of their operations. See also Callen et al (2003), and Ebrahim (2003). Having a social nature, MFIs are suitable candidates to adopt this positive habit.

Specific methodologies to assess MFIs social aspects are being developed. They try to measure MFIs impact in the fight against poverty. AIMS (Assessing the Impact of Microenterprise Services) tries to measure how microfinance interacts with its borrowers' lives, placing families at the centre of the analysis. IMP-ACT (IMProving the impact of MFI on poverty: ACTion Research Programme) is an international program that aims at improving the quality of microfinancial services and their impact on fighting poverty. SROI (Social Return On Investment) attempts to measure, in the form of an investment ratio, the social and environmental value created by an organization, not necessarily a MFI. PAF (Accion Poverty Assessment Framework) compares socio-economic characteristics of its clients against national and international poverty lines. PAT (Poverty Assessment Tool of CGAP) measures poverty outreach by placing MFI clients in the context of the non-clients; see Zeller et al. (2002). SPI (Social Performance Indicators Initiative) goes beyond poverty outreach, screening MFI social responsibility. It has been developed by CERISE (Comité d'Echange, de Réflexion et 
d'Information sur les Systèmes d'épargne crédit), a French microfinance think tank; Zeller et al (2003).

The thirteen MFIs rating agencies from Table 1 have been surveyed to discover specific social assessment. There were only three rating agencies that claim to study MFIs social performance: Microrate, Planet Rating, and M-CRIL. Microrate is a US company specialized in the rating of Latin-American MFIs. MFIs "striving to balance a clear and rational relationship among the social, financial and operational considerations of sound microfinance practice" will obtain a good rating. Planet Rating is a European company that evaluates MFIs worldwide. It uses its own methodology, called GIRAFE (Governance and decision making process, Information and management tools, Risk analysis and control, Assets including loan portfolio, Funding and Efficiency and profitability). They have developed GIRAFE-S, which includes social evaluation and is based on the previously mentioned CERISE. The first MFI assessed under this methodology was Enda, from Tunisia, in 2005. Micro-Credit Ratings International Limited (M-CRIL), a specialized microfinance credit rating agency has recently launched a new social rating service for MFIs. This social rating considers the MFI adherence to its social mission, the depth of outreach to low income clients, and the suitability of products to client needs. In 2004 they conducted a pilot rating exercise in India, evaluating the social performance of BWDA.

To conclude this section, we feel that there are too many small rating firms, employing different methodologies and puzzling rating scales. As Levich et al (2002) point out, "U.S. currently has three general-purpose bond rating firms and has never had more than five in operation at any given time". By contrast, nowadays there are up to 13 MFIs rating agencies. For rating firms, reputation is a key issue, Jansson (2003); and unknown small companies can hardly obtain reputation in their business. Moreover, agencies assign letters as rating grades, and the same letter can have different meanings depending on the rating agency. This is misleading. We agree with the opinion that nowadays, specialized microfinance ratings are hard to compare; Tulchin (2003) and Meehan (2005). After having examined the different methodologies, we feel that most of them have been built adopting banking grades and not taking into account specific microfinance issues, missing the assessment of its social performance. This will be a matter of further discussion. 


\section{Hypotheses}

A series of hypotheses pertaining to MFIs rating are discussed in this section. They relate the rating assigned with MFIs social and financial performance.

\subsection{Size and rating}

Empirical literature recognizes the relevance of company size as an explanatory variable of rating. Pioneer studies, such as Horrigan (1966), Pogue and Soldofsky (1969), or Ederington (1985) included variables measuring size like assets, number of employees, or turnover. Larger MFIs are supposed to have better capability to meet their commitments. A reasonable hypothesis is:

H1. There is a positive and significant relationship between MFI size and rating assigned.

\subsection{Profitability and rating}

Most of the studies find a significant relationship between profitability variables and rating. See Pogue and Soldofsky (1969), Pinches and Mingo (1973), or Poon et al (1999). Companies with better returns will have more capacity to meet their financial obligations, and therefore, get a good rating. A reasonable hypothesis is:

$\mathrm{H} 2$. There is a positive and significant relationship between MFI profitability and rating assigned.

\subsection{Efficiency and rating}

MFIs are financial institutions. Efficiency is a crucial aspect of every financial institution, which implies the rational use of inputs and outputs. Efficiency is the way to survival. Banking industry has developed their own indicators relating different internal measures such as operating expenses, margins, revenues, etc., to obtain productivity and 
efficiency indicators. Those indicators can have a ratio form or can be based on the micro economic theory of production functions. See, for example, Bremer and Pettway (2002) about efficiency and rating in the banking sector. A reasonable hypothesis is:

H3. There is a positive and significant relationship between MFI efficiency and rating assigned.

\subsection{Risk and rating}

To think about rating means to think about risk. Risk is a key issue in the rating process because the rating expresses the likelihood of company to meet its repayment commitments. Poon et al (1999) find a significant relationship between risk variables and rating assigned to financial institutions. A reasonable hypothesis is:

H4. There is a negative and significant relationship between MFI risk and rating assigned.

\subsection{Social performance and rating}

We already stated that MFIs have a social goal. Should the rating incorporate social performance issues? Or, would it be necessary to create specific ratings to measure social performance? If MFIs with good social performance have also a good financial performance, only one rating will be necessary. Arguments in favor of MFIs are that the poor give back their credits. For example, Grameen Bank, well known as a successful model that has surpassed the frontiers of the MFI world, has reported repayment rates of $98 \%$ serving over two million landless borrowers; Morduch (1999). Also, lending rates are high enough to guarantee MFI survival; Conning (1999); and MFIs reaching their social aims are able to get more money from donors. However, empirical research shows that it is difficult to discover MFIs excelling in both the social and financial fields; Morduch (2000). Facing this dilemma, we will not take part for any alternative, but the hypothesis to be tested will be written as follows:

H5. There is a positive and significant relationship between MFI social performance and rating assigned. 


\section{Empirical study}

In this section we describe an empirical study whose aim is to contrast the hypothesis beforehand put forward.

\subsection{Sample}

The immaturity of MFI rating industry forces us to focus our analysis in global risk assessments. The impossibility of comparing the different ratings issued by the rating agencies compel us to concentrate in only one agency. For each agency in Table 1 we have examined the number of MFIs analyzed, and the availability of ratings assigned. We have scanned the rating agency web pages, and also Rating Fund, earlier described, and MIX Market. The MIX Market is a global, web-based, microfinance information platform started as an UNCTAD project (United Nations Conference on Trade and Development).

The rating agency that has more reports available is Planet Rating. This is why it was chosen to conduct the empirical research. So far, this specialized microfinance rating agency has analyzed 145 MFIs worldwide. It has developed the GIRAFE methodology, which was previously described. Planet Rating evaluates three kinds of sustainability: financial, organizational and operational. The first one, financial sustainability, analyses the MFI cost coverage and the sources of funding. The second one, organizational sustainability, looks into the organization: human resources, procedures, information systems and strategy. The last one, operational sustainability, measures the size of the market and the demand of the MFI. The rating method has 19 factors rated from "0" (lowest score) to "5" (highest score). A weighting system applied to the scores gives a rating for each of the six GIRAFE components as well as the final rating. The overall rating, ranging from A (excellent) to $\mathrm{E}$ (immediate risk of default), is described in Table 2.

$* * * *$

Table 2 about here

$* * * *$

The total number of ratings available to us is 70 . There are 2 from year 2000, 7 from year 2001, 15 from year 2002, 25 from year 2003, and 21 from year 2004. Table 2 includes the 
frequency of each rating grade. $18.57 \%$ of MFIs achieve "A", but none of them gets the superior level, “A+". "B" grades are predominant, made up of $55.71 \%$. Grade "C" is obtained by $22.86 \%$ MFIs. Only the $2.86 \%$ are given " $D$ " and none of them is assigned " $E$ ".

\subsection{Variables}

The quality of the information issued by MFIs has been traditionally low, but some improvements are being made, especially since CGAP agreed a set of disclosure guidelines for MFIs financial reporting, in an attempt to improve the standardization of the MFIs financial information, CGAP (2003). It has also been difficult, until recently, to compare the financial information issued by the MFIs, because of the lack of standardization. The efforts to draw guidelines are being successful; see for example Rosemberg et al (2003). Each day, more MFIs are putting into practice common guidelines to disclose financial information.

Table 3 show the 22 variables used, that try to capture the necessary information to contrast the hypothesis stated before. Financial and social information come from Planet Rating reports and MIX Market database.

$$
* * * *
$$

Table 3 about here

$$
* * * *
$$

1) Size. Size can be measured in a number of ways. As a first indicator, we have selected Total Assets (TA). For a second measure, since MFIs are financial institutions, we have chosen the Gross Loan Portfolio (GLP). Two growth ratios have also been calculated: Loan Portfolio Growth (LPG) and Total Assets Growth (TAG).

2) Profitability. We have calculated four financial ratios. The first two are classical profitability measures: Return on Assets (ROA), and Return on Equity (ROE). We have then broken down profitability in two terms: Profit Margin (PM) and Assets Rotation (ROT).

3) Efficiency and productivity. We have incorporated five ratios. Cost per Borrower (CB) is calculated dividing Operating Expense by the Period Average Number of Active Borrowers. If we divided Operating Expense by the Period Average Gross Loan Portfolio, we obtain the OE/LP ratio. Financial Efficiency ratio (EF) places in the denominator Net Operating 
Income. This is a classical banking efficiency ratio. Another ratio is Operating Expense divided by Total Assets (OE/TA). Operational Self-sufficiency (OSS) is a productivity ratio, which measures how well the MFI cover its expenses with revenue from loan portfolio.

4) Risk. We have selected 3 ratios to assess loan portfolio risk. Two of them measure the risk incurred by the MFI. Portfolio at Risk (PAR) divides the Portfolio at Risk outstanding greater than 30 days by the Gross Loan Portfolio. The Write-off ratio (WOFF) gives us information about the percentage of the loan portfolio written-off. The third ratio is the Risk Coverage ratio (RISK), which measures how the MFI covers itself against losses from loan portfolio.

5) Social performance. Up to this point, we have only taken into account financial aspects, in the same way a financial analyst would act. Let us put ourselves in a donor's shoes to select the following social performance indicators.

A donor will appreciate MFIs whose employees process, in average, many loans. The ratio Borrowers per Employee (B/E) have been selected. This is a ratio suitable for many financial institutions, but in reference to MFIs it takes a special meaning, because in this context, the number of people serviced matters. Indeed, MFIs are the opposite to Private Banks, whose aim is to deliver personalized financial solutions to the smallest and selected number of wealthy individuals. Following the same reasoning, we consider a MFI more socially conscious if it grants many tiny loans instead of a small number of larger ones. Therefore, the Average Loan Balance per Borrower (L/B) has been chosen. The information obtained with this ratio can be misleading if the country level of income is not accounted for. So a new ratio, weighting by the Gross National Income per capita, has been derived (L/Bgni).

Not only is it important the number of loans and the amount of them, but also who is receiving the money. Considering the same social aims, it would be expected that loans will be given to disadvantaged people, for example, women and poor. According to Daley-Harris (2005), 66.6 percent of MFIs clients were among the poorest when they took out their first loan. Of these poorest clients, 83.5 percent are women. Microcredit empowers women strengthening their economic activity; Hashemi et al (1996); and then, they can play an active role in the development process; Goetz and Gupta (1996). Microcredit contributes to the fight against vulnerability and poverty; Matin et al (2002). A microcredit strategy is much more likely to bring about general welfare effects and economic growth than a macroeconomic policy; Karim and Osada (1998). Then, we have included for each MFI the Percentage of Loans below US\$ 300 (LBL), to measure the outreach to the poor, and the Percentage of Women Borrowers (WB). 
Finally, it would be expected that MFIs charge interest rates far from usury, considering the average country lending rate. Given two MFIs from the same country, the more socially aware will be that one charging the lower lending rate. The last ratio is the Average MFI Lending Rate minus the Country's Lending Rate divided by the Country's Lending Rate (DIF).

\subsection{Results}

Rating research has traditionally employed different multivariate statistical techniques: Factor Analysis (Pinches and Mingo, 1973); Discriminant Analysis (Mangiameli and West, 1999); Multidimensional Scaling (Mar Molinero et al, 1996); and Ordinal Regression (Poon et al, 1999). We have chosen for testing the hypotheses an exploratory analysis, two nonparametric tests, Spearman's coefficient correlations and an Ordinal Regression.

Table 4 shows a first exploration of the data. We have combined the 11 grades into 3 groups called A, B, and C. Group A includes "A+", "A" and "A-"; group B includes "B+", "B" and "B-"; and finally, the group $\mathrm{C}$ includes the rest of the grades "C+", "C", "C-", "D" and "E". Table 4 allows us to do a first exploration of average values (mean and median) for each group, which reveals if there are differences in each variable for each group. To test if these differences are statistically significant, we have performed two non-parametric tests, whose results are shown in the last two columns. Non-parametric tests are the classic Kruskal-Wallis test and the Jonckheere-Terpstra test, which is more suitable for ordinal data.

$* * * *$

Table 4 about here

$* * * *$

Table 5 shows more results, but this time using the 11 grades from Planet Rating scale. We have calculated Spearman's correlation coefficients between the rating and each variable. The table also shows the results of an ordinal regression. Our main interest is to test the significance of each variable, rather than develop a prediction model. Each one of the 22 variables accounts for a different ordinal regression model. The Wald statistic value is showed to test the significance of individual independent variables. The next columns reveal goodness of fit: Nagelkerke R-square, Chi-square, and Log Likelihood. The last column is the accuracy rate. 
We have considered a classification as being correct if it has predicted the exact grade or if the predicted category was off by one grade; Ang and Pattel (1975).

$$
* * * *
$$

Table 5 about here

$$
* * * *
$$

On the relationship between MFI size and rating, Table 4 allows us to realize that, on average, larger institutions receive better ratings. These differences are significant according to the two non-parametric tests, both considering Total Assets and Gross Loan Portfolio. Spearman's correlation coefficient (Table 5) between grades and size is also positive and significant. Ordinal regression also confirms these results. We conclude that Hypothesis 1 is supported by the data: there is a positive and significant relationship between MFI size and rating assigned. We have not found significant differences when growth ratios are considered.

Hypothesis 2 relates MFIs profitability and rating. MFIs with higher ROA and ROE ratios get better ratings (Table 4). They also have higher margins. The differences are significant according to the non-parametric tests. Spearman's coefficients show positive and significant correlations between profitability variables and rating (Table 5). The results from ordinal regression are also consistent. We conclude that Hypothesis 2 is supported by the data; there is a positive and significant relationship between MFI profitability and rating assigned. The rotation ratio does not show significant differences.

When efficiency and productivity ratios are examined, we notice that average values are better in MFIs receiving good rating grades (Table 4). However, only two ratios show statistically significant differences: OSS -Operational Self-sufficiency, and OE/LP -Operating Expense / Period Average Gross Loan Portfolio. OSS is the ratio that achieves the higher significance value, revealing that it is one of the key ratios for the rating process. By contrast, the OE/LP ratio is significant only at the 0.05 level. We conclude that Hypothesis 3 is supported by the data; there is a positive and significant relationship between MFI productivity and rating assigned.

When examining risk indicators, results are also as expected. There are significant differences, but at the 0.05 level. We conclude that Hypothesis 4 is supported by the data; there is a negative and significant relationship between MFI risk and rating assigned. 
Finally, we analyze social performance indicators and their relationship with rating. In general, no significant differences are observed (Tables 4 and 5), which led us to reject Hypothesis 5, concluding that there is not a significant relationship between MFIs social performance and rating assigned. Only one variable shows significant differences: Percentage of Loans below US\$ 300 (LBL). There is a negative correlation between LBL and rating, significant at the 0.05 level. But this data was only available for 21 MFIs; it is necessary to be very careful when establishing general conclusions. For this reason, we have decided to analyze each MFI individually. We have found several MFIs obtaining low ratings (C or D), but with outstanding social performance, surpassing the rest of institutions. Indeed, some of them target women under poverty line, following their Institutional Mission. According to the financial analysis from their accounting statements, the rating assigned is correct. But these MFIs, which rely on money from donors, run the risk of having their funds reduced, if donors only look at those financial ratings. To avoid this situation, socially aware MFIs could abandon the poorest of the poor and move upwards the poverty scale, searching a more profitable niche market. We propose that MFIs rating agencies should consider social aspects in rating assessments, like some of them are starting to do. A pragmatic suggestion could be to add a further symbol to the rating grade, measuring the accomplishment of social performance objectives.

\section{Conclusions}

The development of MFIs has caused the emergence of specialized MFIs rating agencies. These agencies are certainly necessary, because they provide donors and investors with valuable information about MFI performance. They allow the indispensable transparency in MFIs world. As MFIs get funds in a competitive way, rating exercises should be more frequent. Since MFI bond issues are scarce, actual ratings take mainly the form of global risk assessments.

We have found an incipient sector giving clear signals of reaching maturity. This is verified by examining the quantity and quality of the reports issued on a yearly basis. In comparison with conventional rating sector, there are too many agencies producing a too small number of reports every year. The mixture of rating grades from different agencies seems a hotchpotch, making comparisons a difficult task. Acting this way, it is hard for rating agencies to acquire the necessary recognition from the industry. Some improvements are needed, for example, the development of common guidelines, and the homogenization of the meaning in rating grades. 
A series of hypotheses have been conjectured that relate MFIs rating with financial features. We propose as explicative variables those suggested by traditional rating research in financial institutions (size, profitability, efficiency and productivity, and risk). The hypotheses have been tested empirically. We have collected accounting information from MFIs, and ratings assigned by Planet Rating, a leading agency. As expected, the data reveals a positive and significant relationship between rating and size. It was also established a positive and significant relationship between rating and profitability. The relationship between rating and productivity is also positive and significant. Finally, the data supports a negative and significant relationship between rating and risk. These findings are coherent with theory, enhancing the value of ratings for investors.

Six indicators related to social performance have then been calculated. No significant relationship between rating and social performance has been found.

We have identified some MFIs which are weak in financial aspects, and so, they have been given a low rating. By contrast, they outperform other MFIs in social indicators. They lend very small sums of money to the poorest. From the point of view of financial statement analysis nothing can be said, but they can be penalized when receiving funds from donors. Especially if socially responsible investors put their eyes in MFIs ratings, and are not aware that rating scores only concern financial matters. We can not forget that MFIs have a double nature, financial and social, and both outputs have to be carefully assessed. In our opinion, it is crucial that rating agencies progress in the development of social ratings, as a complement of financial ratings. 


\section{References}

Adams, D. W., \& Von Pischke, J. D. (1992). Microenterprise Credit Programs: Déjà Vu. World Development, 20(10), 1463-1470.

Ang, J., \& Patel, K. (1975) Bond Rating Methods: Comparison and Validation. Journal of Finance, 30, 631-640.

Bongini, P., Laeven, L., \& Majnoni, G. (2002). How good is the market at assessing bank fragility? A horse race between different indicators. Journal of Banking \& Finance, 26(5), 1011-1028.

Bostic, R. W., \& Robinson, B. L. (2004). The impact of CRA agreements on community banks. Journal of Banking \& Finance, 28(12), 3069-3095.

Bremer, M., \& Pettway, R.H. (2002). Information and the market's perceptions of Japanese bank risk: Regulation, environment, and disclosure. Pacific-Basin Finance Journal, 10(2), 119-139.

Callen, J. L., Klein, A., \& Tinkelman, D. (2003). Board Composition, Committees, and Organizational Efficiency: The Case of Nonprofits. Nonprofit and Voluntary Sector Quarterly, $32,493-520$

CGAP (2003). Microfinance consensus guidelines. Definitions of selected financial terms, ratios and adjustments for microfinance, 3rd edition. Washington D. C.: Consultative Group to Assist the Poorest

Conning, J. (1999). Outreach, sustainability and leverage in monitored and peermonitored lending. Journal of Development Economics, 60, 51-77.

Daley-Harris, S. (2005). State of the Microcredit Summit Campaign Report 2005. Washington D.C.: Microcredit Summit Campaign.

Dichter, T. W. (1999). Globalization and Its Effects on NGOs: Efflorescence or a Blurring of Roles and Relevance? Nonprofit and Voluntary Sector Quarterly, 28, 38-58.

Ebrahim, A. (2003). Accountability In Practice: Mechanisms for NGOs. World Development, 31(5), 813-829. 
Ederington, L.H. (1985). Classification models and bond ratings. Financial Review, 20(4), 237-262.

Ferri, G., Liu, L. G., \& Majnoni, G. (2001). The role of rating agency assessments in less developed countries: Impact of the proposed Basel guidelines. Journal of Banking \& Finance, 25(1), 115-148.

Goetz, A.M., \& Gupta, R.S. (1996). Who takes the credit? Gender, Power and Control over Loan Use in Rural Credit Programmes in Bangladesh. World Development, 24(1), 45-63.

Gutiérrez-Nieto, B., Serrano-Cinca, C., \& Mar Molinero, C. (2006). Microfinance Institutions and Efficiency. Omega, forthcoming, doi:10.1016/j.omega.2005.04.001.

Hartarska, V. (2005). Governance and Performance of Microfinance Institutions in Central and Eastern Europe and the Newly Independent States. World Development, 33(10), $1627-1643$.

Hashemi, S.M., Schuler, S.R., \& Riley, A.P. (1996). Rural Credit Programs and Women Empowerment in Bangladesh. World Development, 24(4), 635-653.

Horrigan, J. O. (1966). The Determination of Long-Term Credit Standing with Financial Ratios. Journal of Accounting Research, Supplement, Empirical Research in Accounting, Selected Studies, 44-62.

Hulme, D., \& Mosley, P. (1996). Finance against Poverty. 2 Volumes. London: Routledge.

Jansson, T. (2003). Financing Microfinance, Inter-American Development Bank Sustainable Development Department Technical Paper Series, MSM-118. Washington D.C.

Johnson, S. A. \& Sarkar, S. K. (1996). The valuation effects of the 1977 Community Reinvestment Act and its enforcement. Journal of Banking \& Finance, 20(5), 783-803.

Kaplan, R.S., \& Urwitz, G. (1979). Statistical models of bond ratings: a methodological inquiry. Journal of Business, 52(2), 231-261.

Karim, M.R., \& Osada, M. (1998). Dropping out: An emerging factor in the success of Microcredit-based poverty alleviation programs. Developing Economies, 36(3), 257-288. 
Levich, R.M., Majnoni, G. \& Reinhart, C. (2002). Ratings, Rating Agencies and the Global Financial System. New York: Kluwer Academic Publishers

Lindenberg, M. (2001). Reaching Beyond the Family: New Nongovernmental Organization Alliances for Global Poverty Alleviation and Emergency Response. Nonprofit and Voluntary Sector Quarterly, 30, 603-615.

Mangiameli, P. \& West, D. (1999). An improved neural classification network for the two-group problem. Computers \& Operations Research, 26(5), 443-460.

Manne, G. A. (1999). Agency costs and the oversight of charitable organizations. Wisconsin Law Review, (2), 227-272.

Mar Molinero, C., Apellániz, P., \& Serrano Cinca, C. (1996). A Multivariate Analysis of Spanish Bond Ratings. Omega, 24 (4), 451-462.

Matin, I., Hulme, D., \& Rutherford, S. (2002). Finance for the Poor: From Microcredit to Microfinancial Services. Journal of International Development, 14(2), 273-294.

Meehan, J. (2005). Tapping financial markets to microfinance. Washington D. C.: Grameen Bank Foundation USA.

Morduch, J. (1999). The role of subsidies in microfinance: evidence from the Grameen Bank. Journal of Development Economics, 60(1), 229-248.

Morduch, J. (2000). The Microfinance Schism. World Development, 28(4), 617-629.

Morgan, D. P. (2002). Rating banks: Risk and uncertainty in an opaque industry. American Economic Review, 92(4), 874-888.

Pinches, G. E., \& Mingo, K. A. (1973). A multivariate analysis of industrial bond ratings. Journal of Finance, 28(1), 1-18.

Pogue, T. F. \& Soldofsky, R. M. (1969). What's in a Bond Rating? Journal of Financial and Quantitative Analysis, 4(2), 201-228.

Poon, W. P. H. (2003). Are unsolicited credit ratings biased downward? Journal of Banking \& Finance, 27(4), 593-614. 
Poon, W. P. H., Firth, M., \& Fung, H.-G. (1999). A multivariate analysis of the determinants of Moody's bank financial strength ratings, Journal of International Financial Markets, Institutions and Money, 9, 267-283.

Rosenberg, R., Mwangi, P., Christen, R. P., \& Nasr, M. (2003). Microfinance Consensus Guidelines. Disclosure guidelines for financial reporting by microfinance institutions. Washington D. C.: CGAP (Consultative Group to Assist the Poorest)

Tucker, M. (2001). Financial Performance of Selected Microfinance Institutions. Journal of Microfinance, 3(2), 107-123.

Tulchin, D. (2003). Microfinance's Double Bottom Line, Social Enterprise Associates' Emerging Topics Paper Series 1. Washington D. C.: Social Enterprise Associates.

Woller, G. M., Dunford, C., \& Woodworth, W. (1999). Where to Microfinance? International Journal of Economic Development, 1(1), 29-64.

Yaron, J. (1994). What Makes Rural Finance Institutions Successful? The World Bank Research Observer, 9(1), 49-70.

Zeller, M., Sharma, M., Henry, C., \& Lapenu, C. (2002). An operational tool for evaluating poverty outreach of development policies and projects. In M. Zeller, \& R. L. Meyer (eds): The Triangle of Microfinance. Baltimore and London: John Hopkins University Press.

Zeller, M., Lapenu, C., \& Greeley, M. (2003). Social performance indicators initiative (SPI). Initiating memorandum, March. Comite d'Echange, de Reflexion et d'Information sur les systemes d'Epargne-credit (CERISE). 


\begin{tabular}{|c|c|c|c|}
\hline Name & Description & Analysis & Grades \\
\hline $\begin{array}{r}\text { Apoyo \& } \\
\text { Asociados }\end{array}$ & $\begin{array}{l}\text { Formal rating agency affiliated to } \\
\text { Fitch Ratings. It has conducted } 86 \\
\text { assessments to Latin American MFIs. }\end{array}$ & $\begin{array}{l}\text { It issues a report containing information about: equity, performance, } \\
\text { credit risk, funds diversification, market situation, operational and } \\
\text { technological risks, management and ownership, and future trends. }\end{array}$ & A; B; C; D; E \\
\hline $\begin{array}{r}\text { Accion } \\
\text { International }\end{array}$ & $\begin{array}{l}\text { Non-for-profit network of MFls based } \\
\text { in USA. It has assessed } 56 \text { MFIs in } \\
\text { Latin America, Africa, CEE (Central } \\
\text { and Eastern Europe)/NIS (Newly } \\
\text { Independent States) and South Asia. }\end{array}$ & $\begin{array}{l}\text { It has adapted the CAMEL rating methodology to perform global risk } \\
\text { assessments of MFIs. The CAMEL methodology assesses } 21 \text { indicators } \\
\text { under } 5 \text { areas: Capital adequacy, Asset quality, Management, Earnings } \\
\text { and Liquidity management. }\end{array}$ & $\begin{array}{l}\text { AAA; AA; A; } \\
\text { BBB; BB; B; } \\
\text { CCC; CC; C; } \\
\text { DDD; DD; D }\end{array}$ \\
\hline Classrating & $\begin{array}{l}\text { Formal specialized rating agency that } \\
\text { has undertaken, so far, more than } 20 \\
\text { assessments to Latin American MFIs. }\end{array}$ & $\begin{array}{l}\text { The assessment of bonds, debt, shares and financial strength (global } \\
\text { risk assessment) of financial institutions takes } 5 \text { steps: information } \\
\text { analysis, solvency analysis, liquidity analysis, issue's contract analysis } \\
\text { and final classification. }\end{array}$ & A; B; C; D; E \\
\hline Equilibrium & $\begin{array}{l}\text { Formal rating agency that conducts } \\
\text { credit rating assessments to Latin } \\
\text { American MFIs. So far it has } \\
\text { conducted } 13 \mathrm{MFI} \text { assessments. }\end{array}$ & $\begin{array}{l}\text { It performs a quantitative analysis, focused on asset quality, capital } \\
\text { adequacy, profitability, liquidity, balance sheet mix, funding strengths } \\
\text { and weaknesses, cash flows, and so on. On the other hand, } \\
\text { qualitatively, it assesses the management quality, business } \\
\text { diversification and financial flexibility. }\end{array}$ & A; B; C; D; E \\
\hline Feller rate & $\begin{array}{l}\text { Formal rating agency, Standard and } \\
\text { Poor's strategic alliance partner, that } \\
\text { so far has conducted } 8 \text { assessments } \\
\text { to Latin American MFls. }\end{array}$ & $\begin{array}{l}\text { The rating is based both in solvency classification and product's own } \\
\text { characteristics. For debt titles assessments, Feller examines } \\
\text { guarantees, which can lead to different repayment capacities. }\end{array}$ & $\begin{array}{l}\mathrm{AAA} ; \mathrm{AA} ; \mathrm{A} ; \\
\mathrm{BBB} ; \mathrm{BB} ; \mathrm{B} ; \\
\mathrm{CCC} ; \mathrm{CC} ; \mathrm{C} ; \\
\mathrm{DDD} ; \mathrm{DD} ; \mathrm{D}\end{array}$ \\
\hline Fitch rating & $\begin{array}{l}\text { International formal rating agency, It } \\
\text { conducts credit ratings and global } \\
\text { risk assessments. So far, its Chilean } \\
\text { branch has performed assessments } \\
\text { to } 20 \text { Latin American MFls. }\end{array}$ & $\begin{array}{l}\text { The rating is a comprehensive qualitative and quantitative assessment } \\
\text { of strengths and weaknesses of the institution. Quantitative aspects e.g. } \\
\text { balance sheet integrity, or profitability and risk management are } \\
\text { counterbalanced by qualitative considerations about strategy, } \\
\text { management quality, environment issues and future perspectives. }\end{array}$ & $\begin{array}{l}\text { AAA; AA; A; } \\
\text { BBB; BB; B; } \\
\text { CCC; CC; C; } \\
\text { DDD; DD; D }\end{array}$ \\
\hline $\begin{array}{l}\text { Planet } \\
\text { Rating }\end{array}$ & $\begin{array}{l}\text { French non-for-profit organization. It } \\
\text { has developed the GIRAFE } \\
\text { methodology. So far it has analysed } \\
78 \text { MFIs of Africa, Latin America, } \\
\text { East Asia, CEE /NIS and MENA } \\
\text { (Middle East and North Africa). }\end{array}$ & $\begin{array}{l}\text { GIRAFE means Governance and decision making process, Information } \\
\text { and management tools, Risk analysis and control, Assets including loan } \\
\text { portfolio, Funding (equity and liabilities) and Efficiency and profitability. It } \\
\text { evaluates three kinds of sustainability: financial, organizational and } \\
\text { operational. }\end{array}$ & $\begin{array}{l}\mathrm{A}+; \mathrm{A} ; \mathrm{A}-; \mathrm{B}+; \\
\mathrm{B} ; \mathrm{B}-; \mathrm{C}+; \mathrm{C} ; \mathrm{C}- \\
; \mathrm{D} ; \mathrm{E}\end{array}$ \\
\hline$M-C R I L$ & $\begin{array}{l}\text { Indian specialized microfinance rating } \\
\text { agency. It has conducted } 185 \\
\text { assessments of MFls from South } \\
\text { Asia, East Asia and the Pacific and } \\
\text { CEE/NIS. }\end{array}$ & $\begin{array}{l}\text { It uses a rating tool with three categories of indicators: governance and } \\
\text { strategy, management systems, and financial performance. }\end{array}$ & $\begin{array}{l}\alpha+++; \alpha++; \alpha+; \\
\alpha ; \alpha-; \beta+; \beta ; \beta-; \\
\gamma+; \gamma\end{array}$ \\
\hline JCR-VIS & $\begin{array}{l}\text { Pakistani formal rating agency. It } \\
\text { mainly performs credit ratings and } \\
\text { has conducted } 5 \text { assessments of } \\
\text { South Asian MFls. }\end{array}$ & $\begin{array}{l}\text { It uses a methodology called MIRACLES, the acronym for Management, } \\
\text { Information Systems, Reputation, Asset quality, Capital, Liquidity, } \\
\text { Earnings and Supervisory systems (internal and external). }\end{array}$ & $\begin{array}{l}\mathrm{AAA} ; \mathrm{AA} ; \mathrm{A} ; \\
\mathrm{BBB} ; \mathrm{BB} ; \mathrm{B} ; \\
\mathrm{CCC} ; \mathrm{CC} ; \mathrm{C} ; \\
\mathrm{DDD} ; \mathrm{DD} ; \mathrm{D}\end{array}$ \\
\hline Microfinanza & $\begin{array}{l}\text { Italian specialized microfinance rating } \\
\text { agency. It has completed } 20 \\
\text { assessments to MFIs in Africa, } \\
\text { CEE/NIS, Latin America, and South } \\
\text { Asia. }\end{array}$ & $\begin{array}{l}\text { It performs a quantitative and qualitative assessment of strengths and } \\
\text { weaknesses of the MFI, to grade the risk on two categories: fiduciary } \\
\text { risk (related to governance and management) and credit risk (obligations } \\
\text { repayment ability). }\end{array}$ & $\begin{array}{l}\text { AAA; AA; A; } \\
\text { BBB; BB; B; } \\
\text { CCC; CC; C; } \\
\text { DDD; DD; D }\end{array}$ \\
\hline Microrate & $\begin{array}{l}\text { Specialized microfinance rating } \\
\text { agency based in the USA. It has } \\
\text { conducted } 172 \text { MFIs assessments in } \\
\text { Latin America and Africa. }\end{array}$ & $\begin{array}{l}\text { For this agency, there is no unique criterion applying equally to all MFIs. } \\
\text { It tries to identify this hierarchy correctly for each analysis. But the } \\
\text { criteria ranked most frequently are: portfolio quality, operational } \\
\text { effectiveness, management and governance. }\end{array}$ & $\begin{array}{l}\alpha++; \alpha+; \alpha ; \alpha-; \\
\beta+; \beta ; \beta-; \gamma+; \gamma \\
\gamma-\end{array}$ \\
\hline CRISIL & $\begin{array}{l}\text { Rating agency with specialized } \\
\text { microfinance practice. So far, it has } \\
\text { conducted } 18 \text { assessments of MFIs } \\
\text { from Southeast Asia. }\end{array}$ & $\begin{array}{l}\text { It has developed the MICROS methodology, with six indicators: } \\
\text { Management } 25 \% \text {, Institutional Arrangement } 15 \% \text {, Capital Adequacy \& } \\
\text { Asset Quality } 20 \% \text {, Resources } 10 \% \text {, Operational Effectiveness } 15 \% \text {, } \\
\text { and Scalability \& Sustainability } 15 \% \text {. }\end{array}$ & $\begin{array}{l}\text { mfR1; } m f R 2 ; \\
\text { mfR3; mfR4; } \\
\text { mfR5; mfR6; } \\
\text { mfR7; mfR8; }\end{array}$ \\
\hline $\begin{array}{r}\text { Pacific } \\
\text { Credit Rating }\end{array}$ & $\begin{array}{l}\text { Formal rating agency that mainly } \\
\text { conducts credit ratings. It has } \\
\text { undertaken } 7 \text { assessments to Latin } \\
\text { American MFls. }\end{array}$ & $\begin{array}{l}\text { The rating exercise studies quantitative and qualitative information. } \\
\text { Qualitative aspects are considered very important and are based on } \\
\text { fundamental principles. Complete analytic revisions are undertaken to } \\
\text { assess the financial health of the institution. Then, future financial results } \\
\text { are estimated, which will allow future rating revisions. }\end{array}$ & $\begin{array}{l}\mathrm{m} 1 ; \mathrm{m} 2 ; \mathrm{m3} ; \\
\mathrm{m} 4 ; \mathrm{m} 5 ; \mathrm{m} 6 ; \\
\mathrm{m7} ; \mathrm{m8} ; \mathrm{m} 9 ; \\
\mathrm{m} 10 ; \mathrm{m} 11 ; \\
\mathrm{m} 12 ; \mathrm{m} 13 ; \mathrm{m} 14\end{array}$ \\
\hline
\end{tabular}

Table 1. Specialized MFIs rating agencies. 


\begin{tabular}{|c|c|c|c|}
\hline Grade & $\begin{array}{l}\text { Frequency in } \\
\text { the sample. } \\
\quad \mathrm{N}=70\end{array}$ & $\begin{array}{l}\text { Percentage in } \\
\text { the sample }\end{array}$ & Description \\
\hline$A+$ & 0 & 0 & \multirow{3}{*}{$\begin{array}{l}\text { A, Excellent. The institution excels in the evaluation area and is a } \\
\text { model for the sector. There is a long-term vision for continual } \\
\text { improvement. There are no risks in the short and medium term for } \\
\text { operations. Long-term risks are well managed and monitored. }\end{array}$} \\
\hline A & 6 & 8.57 & \\
\hline A- & 7 & 10 & \\
\hline$B+$ & 18 & 25.71 & \multirow{3}{*}{$\begin{array}{l}\text { B, Good. Procedures are well developed, effective, and incorporate a } \\
\text { long-term perspective. Some improvements could be made. Long- } \\
\text { term risks are identified in the strategic plan. }\end{array}$} \\
\hline B & 10 & 14.29 & \\
\hline B- & 11 & 15.71 & \\
\hline $\mathbf{C +}$ & 8 & 11.43 & \multirow{3}{*}{$\begin{array}{l}\text { C, Minimum required. Procedures are functional but with certain } \\
\text { failings. There are minor risks in the medium term for operations. }\end{array}$} \\
\hline C & 3 & 4.29 & \\
\hline C- & 5 & 7.14 & \\
\hline D & 2 & 2.86 & $\begin{array}{l}\text { D, Insufficient. Procedures are in place, but with failings, and certain } \\
\text { problems are only partially addressed. There are medium-term, and } \\
\text { possibly short-term, risks for operations. }\end{array}$ \\
\hline E & 0 & 0 & $\begin{array}{l}\text { E, Immediate risk of default or very insufficient. There are } \\
\text { immediate or underlying risks for operations or an unacceptable under } \\
\text { performance. }\end{array}$ \\
\hline
\end{tabular}

Table 2. Grades for global risk assessments according to Planet Rating 


\begin{tabular}{|c|c|c|}
\hline & Variable & Definition \\
\hline \multirow{4}{*}{ Size } & TA & Total Assets \\
\hline & GLP & Gross Loan Portfolio \\
\hline & LPG & Loan Portfolio Growth \\
\hline & TAG & Total Assets Growth \\
\hline \multirow{4}{*}{ Profitability } & $\mathrm{ROA}$ & Return on Assets $=($ Net Operating Income - Taxes $) /$ Period Average Assets \\
\hline & $\mathrm{ROE}$ & Return on Equity = (Net Operating Income - Taxes $)$ / Period Average Equity \\
\hline & PM & Profit Margin = Net Operating Income / Financial Revenue \\
\hline & ROT & Financial Revenue / Total Assets \\
\hline \multirow{5}{*}{$\begin{array}{r}\text { Efficiency } \\
\text { and } \\
\text { productivity }\end{array}$} & $\mathrm{CB}$ & Cost per Borrower = Operating Expense/ Period Average Number of Active Borrowers \\
\hline & OE/LP & Operating Expense / Period Average Gross Loan Portfolio \\
\hline & $\mathrm{EF}$ & Financial Efficiency ratio = Operating Expense/Net Operating Income \\
\hline & OE/TA & Operating Expense / Total Assets \\
\hline & OsS & $\begin{array}{l}\text { Self-sufficiency = Financial Revenue / (Financial Expense + Loan Loss Provision } \\
\text { Expense + Operating Expense) }\end{array}$ \\
\hline \multirow{3}{*}{ Risk } & PAR & Portfolio at Risk $>30$ days / Gross Loan Portfolio \\
\hline & WOFF & $\begin{array}{l}\text { Write-off ratio = Write Offs for the 12-month period / Period Average Gross Loan } \\
\text { Portfolio }\end{array}$ \\
\hline & RISK & Risk Coverage ratio = Loan loss Reserves / Portfolio at Risk (31-365 days) \\
\hline \multirow{6}{*}{$\begin{array}{r}\text { Social } \\
\text { performance }\end{array}$} & $\mathrm{B} / \mathrm{E}$ & Borrowers per Employee \\
\hline & L/B & Average Loan Balance per Borrower \\
\hline & L/Bgni & Average Loan Balance per Borrower / Gross National Income per capita \\
\hline & LBL & \% Loans below US $\$ 300$ \\
\hline & WB & \% Women Borrowers \\
\hline & DIF & (Average MFI Lending Rate-Country's Lending Rate) / Country's Lending Rate \\
\hline
\end{tabular}

Table 3. Variables and their definitions. 


\begin{tabular}{|c|c|c|c|c|c|c|c|c|c|c|c|c|c|c|}
\hline \multirow{2}{*}{ Variable } & \multicolumn{4}{|c|}{ Rating $A$} & \multicolumn{4}{|c|}{ Rating B } & \multicolumn{4}{|c|}{ Rating $C-D-E$} & \multirow{2}{*}{$\begin{array}{c}\text { Kruskal } \\
\text {-Wallis } \\
\text { Test }\end{array}$} & \multirow{2}{*}{$\begin{array}{c}\text { Jonckheere } \\
\text {-Terpstra } \\
\text { Test }\end{array}$} \\
\hline & Mean & Median & St dev & $n$ & Mean & Median & St dev & $n$ & Mean & Median & St dev & $n$ & & \\
\hline TA & $21,706,651$ & $18,149,075$ & $13,141,042$ & 13 & $11,176,481$ & $6,473,843$ & $13,735,460$ & 39 & $10,908,688$ & $3,635,328$ & $20,402,996$ & 18 & $13.51^{* *}$ & $1.038^{\star *}$ \\
\hline GLP & $18,053,974$ & $14,248,257$ & $13,152,275$ & 13 & $7,454,707$ & $4,609,011$ & $8,074,558$ & 39 & $7,136,317$ & $1,832,930$ & $11,141,510$ & 18 & $14.95^{\star *}$ & $1.066^{* *}$ \\
\hline LPG & 0.375 & 0.320 & 0.285 & 11 & 0.373 & 0.386 & 0.192 & 26 & 0.869 & 0.269 & 2.444 & 16 & 0.87 & 473.5 \\
\hline TAG & 0.321 & 0.282 & 0.164 & 10 & 0.373 & 0.322 & 0.203 & 26 & 0.174 & 0.116 & 0.244 & 16 & $8.24^{*}$ & $540.5^{*}$ \\
\hline $\mathrm{ROA}$ & 0.085 & 0.097 & 0.039 & 13 & 0.076 & 0.058 & 0.054 & 39 & -0.032 & 0.001 & 0.093 & 17 & $29.17^{\star *}$ & $1.117^{\star *}$ \\
\hline $\mathrm{ROE}$ & 0.188 & 0.187 & 0.098 & 12 & 0.166 & 0.132 & 0.137 & 39 & -0.083 & 0.002 & 0.299 & 17 & $19.26^{* *}$ & $1.024^{\star *}$ \\
\hline PM & 0.322 & 0.331 & 0.107 & 13 & 0.291 & 0.264 & 0.260 & 39 & -0.076 & 0.012 & 0.267 & 18 & $31.12^{* *}$ & $1.192^{* *}$ \\
\hline ROT & 0.247 & 0.263 & 0.083 & 13 & 0.287 & 0.306 & 0.122 & 39 & 0.239 & 0.208 & 0.148 & 17 & 1.98 & 727 \\
\hline CB & 122.804 & 127.000 & 66.956 & 13 & 108.693 & 85.000 & 79.592 & 39 & 171.248 & 120.000 & 211.268 & 17 & 0.85 & 747 \\
\hline OE/LP & 0.171 & 0.176 & 0.059 & 13 & 0.270 & 0.229 & 0.174 & 39 & 0.341 & 0.220 & 0.234 & 17 & 4.51 & $526.5^{*}$ \\
\hline EF & 3.628 & 1.612 & 7.426 & 13 & 5.917 & 2.229 & 9.399 & 39 & 17.409 & 5.541 & 46.392 & 16 & 2.92 & 542 \\
\hline $\mathrm{OE} / \mathrm{TA}$ & 0.139 & 0.145 & 0.050 & 13 & 0.185 & 0.182 & 0.101 & 39 & 0.205 & 0.168 & 0.170 & 17 & $\begin{array}{c}1.75 \\
\cdots\end{array}$ & \begin{tabular}{c}
633 \\
\hdashline
\end{tabular} \\
\hline OSS & 1.504 & 1.487 & 0.232 & 13 & 1.369 & 1.353 & 0.265 & 39 & 0.959 & 1.006 & 0.189 & 18 & $32.18^{\star \star}$ & $1.211^{\star \star}$ \\
\hline PAR & 0.021 & 0.004 & 0.043 & 13 & 0.023 & 0.016 & 0.027 & 39 & 0.060 & 0.036 & 0.101 & 17 & $6.30^{*}$ & $473.5^{* *}$ \\
\hline WOFF & 0.005 & 0.003 & 0.005 & 13 & 0.010 & 0.005 & 0.013 & 38 & 0.056 & 0.034 & 0.091 & 17 & $9.12^{\star}$ & $450^{* *}$ \\
\hline RISK & 3.211 & 2.340 & 2.835 & 11 & 0.937 & 0.497 & 1.127 & 24 & 1.474 & 1.100 & 1.757 & 15 & $9.83^{* *}$ & 435.5 \\
\hline $\mathrm{B} / \mathrm{E}$ & 159.923 & 162.000 & 58.749 & 13 & 166.667 & 147.000 & 113.619 & 39 & 167.278 & 94.500 & 216.072 & 18 & 4.28 & 892.5 \\
\hline L/B & 537.664 & 518.000 & 294.026 & 9 & 500.437 & 245.356 & 653.247 & 34 & 698.817 & 279.861 & 1.135 .738 & 18 & 2.07 & 602.5 \\
\hline L/Bgni & 0.592 & 0.430 & 0.470 & 10 & 0.765 & 0.244 & 1.324 & 37 & 0.837 & 0.191 & 1.462 & 18 & 1.35 & 693 \\
\hline LBL & $24.56 \%$ & $10.00 \%$ & 0.262 & 9 & $42.10 \%$ & $48.50 \%$ & 0.331 & 10 & $76.50 \%$ & $76.50 \%$ & 0.304 & 2 & 3.85 & 36 \\
\hline WB & $71.60 \%$ & $\begin{array}{c}64.90 \% \\
6 \\
\end{array}$ & 0.255 & 11 & $69.48 \%$ & $\begin{array}{l}69.80 \% \\
.6\end{array}$ & 0.225 & 29 & $\begin{array}{l}66.56 \% \\
6\end{array}$ & $\begin{array}{l}60.80 \% \\
6\end{array}$ & 0.276 & 10 & 0.33 & 389 \\
\hline DIF & 1.505 & 1.354 & 0.274 & 3 & 2.170 & 2.486 & 1.935 & 10 & 1.783 & 1.137 & 2.092 & 8 & 0.21 & 70 \\
\hline
\end{tabular}

Table 4. Descriptive statistics. Non-parametric tests. 


\begin{tabular}{|c|c|c|c|c|c|c|c|}
\hline \multirow{2}{*}{ Variable } & \multirow{2}{*}{$\begin{array}{c}\text { Number of } \\
\text { observations }\end{array}$} & \multirow{2}{*}{$\begin{array}{l}\text { Spearman } \\
\text { correlation }\end{array}$} & \multirow{2}{*}{$\begin{array}{l}\text { Wald } \\
\text { statistic }\end{array}$} & \multicolumn{4}{|c|}{ Significance of model } \\
\hline & & & & $\begin{array}{c}\text { Nagelkerke } \\
R \text {-square }\end{array}$ & Chi-square & $\begin{array}{c}\text { Log } \\
\text { Likelihood }\end{array}$ & $\begin{array}{c}\text { Accuracy } \\
\text { rate }\end{array}$ \\
\hline $\operatorname{Ln}(T A)$ & 70 & $0.422^{\star \star}$ & $12.51^{\star *}$ & 0.170 & $12.82^{\star *}$ & 271.64 & 0.54 \\
\hline Ln(GLP) & 70 & $0.451^{* \star}$ & $17.31^{\star \star}$ & 0.236 & $18.45^{* *}$ & 266.01 & 0.56 \\
\hline LPG & 53 & 0.03 & 0.94 & 0.023 & 1.19 & 216.44 & 0.53 \\
\hline TAG & 52 & $0.295^{\star}$ & $3.99^{\star}$ & 0.077 & $4.11^{\star}$ & 210.73 & 0.62 \\
\hline $\mathrm{ROA}$ & 69 & $0.576^{* *}$ & $20.40^{* *}$ & 0.298 & $23.90^{* *}$ & 254.71 & 0.62 \\
\hline $\mathrm{ROE}$ & 68 & $0.475^{\star \star}$ & $15.25^{\star *}$ & 0.233 & $17.66^{* \star}$ & 257.29 & 0.59 \\
\hline PM & 70 & $0.618^{\star *}$ & $18.98^{\star *}$ & 0.263 & $20.94^{\star *}$ & 263.52 & 0.67 \\
\hline ROT & 69 & 0.03 & 0.09 & 0.001 & 0.09 & 279.91 & 0.51 \\
\hline CB & 69 & 0.08 & 0.86 & 0.013 & 0.89 & 269.17 & 0.52 \\
\hline $\mathrm{OE} / \mathrm{LP}$ & 69 & $-0.278^{*}$ & $8.65^{\star *}$ & 0.112 & $8.07^{* \star}$ & 270.54 & 0.54 \\
\hline EF & 68 & -0.23 & 1.79 & 0.032 & 2.17 & 272.38 & 0.53 \\
\hline OE/TA & 69 & -0.13 & $4.66^{*}$ & 0.059 & $4.09^{*}$ & 275.91 & 0.51 \\
\hline OSS & 70 & $0.666^{\star *}$ & $28.89^{\star \star}$ & 0.390 & $33.87^{* \star}$ & 250.59 & 0.63 \\
\hline PAR & 69 & $-0.275^{\star}$ & $4.74^{*}$ & 0.075 & $5.26^{\star}$ & 259.25 & 0.49 \\
\hline WOFF & 68 & $-0.257^{*}$ & $4.28^{*}$ & 0.077 & $5.34^{*}$ & 240.37 & 0.50 \\
\hline RISK & 50 & 0.17 & $5.52^{*}$ & 0.095 & $4.93^{*}$ & 195.59 & 0.54 \\
\hline $\mathrm{B} / \mathrm{E}$ & 70 & 0.22 & 0.10 & 0.001 & 0.07 & 278.84 & 0.50 \\
\hline $\mathrm{L} / \mathrm{B}$ & 61 & 0.15 & 0.12 & 0.002 & 0.15 & 246.26 & 0.49 \\
\hline L/Bgni & 65 & 0.17 & 0.00 & 0.000 & 0.00 & 262.09 & 0.49 \\
\hline $\mathrm{LBL}$ & 21 & $-0.450^{*}$ & $5.08^{*}$ & 0.242 & $5.62^{*}$ & 61.02 & 0.57 \\
\hline WB & 50 & 0.04 & 0.03 & 0.001 & 0.03 & 168.40 & 0.48 \\
\hline DIF & 21 & -0.09 & 0.45 & 0.024 & 0.50 & 85.28 & 0.48 \\
\hline
\end{tabular}

Table 5. Spearman's correlation coefficients. Summary of the results of 22 ordinal regression models.

** Significant at the 0.01 level

* Significant at the 0.05 level. 


\section{Documentos de Trabajo}

\section{Facultad de Ciencias Económicas y Empresariales. Universidad de Zaragoza.}

2002-01: "Evolution of Spanish Urban Structure During the Twentieth Century". Luis Lanaspa, Fernando Pueyo y Fernando Sanz. Department of Economic Analysis, University of Zaragoza.

2002-02: "Una Nueva Perspectiva en la Medición del Capital Humano". Gregorio Giménez y Blanca Simón. Departamento de Estructura, Historia Económica y Economía Pública, Universidad de Zaragoza.

2002-03: "A Practical Evaluation of Employee Productivity Using a Professional Data Base". Raquel Ortega. Department of Business, University of Zaragoza.

2002-04: "La Información Financiera de las Entidades No Lucrativas: Una Perspectiva Internacional". Isabel Brusca y Caridad Martí. Departamento de Contabilidad y Finanzas, Universidad de Zaragoza.

2003-01: "Las Opciones Reales y su Influencia en la Valoración de Empresas". Manuel Espitia y Gema Pastor. Departamento de Economía y Dirección de Empresas, Universidad de Zaragoza.

2003-02: "The Valuation of Earnings Components by the Capital Markets. An International Comparison". Susana Callao, Beatriz Cuellar, José Ignacio Jarne and José Antonio Laínez. Department of Accounting and Finance, University of Zaragoza.

2003-03: "Selection of the Informative Base in ARMA-GARCH Models". Laura Muñoz, Pilar Olave and Manuel Salvador. Department of Statistics Methods, University of Zaragoza.

2003-04: "Structural Change and Productive Blocks in the Spanish Economy: An Imput-Output Analysis for 1980-1994". Julio Sánchez Chóliz and Rosa Duarte. Department of Economic Analysis, University of Zaragoza.

2003-05: "Automatic Monitoring and Intervention in Linear Gaussian State-Space Models: A Bayesian Approach". Manuel Salvador and Pilar Gargallo. Department of Statistics Methods, University of Zaragoza.

2003-06: "An Application of the Data Envelopment Analysis Methodology in the Performance Assessment of the Zaragoza University Departments". Emilio Martín. Department of Accounting and Finance, University of Zaragoza.

2003-07: "Harmonisation at the European Union: a difficult but needed task". Ana Yetano Sánchez. Department of Accounting and Finance, University of Zaragoza.

2003-08: "The investment activity of spanish firms with tangible and intangible assets". Manuel Espitia and Gema Pastor. Department of Business, University of Zaragoza.

2004-01: "Persistencia en la performance de los fondos de inversión españoles de renta variable nacional (1994-2002)". Luis Ferruz y María S. Vargas. Departamento de Contabilidad y Finanzas, Universidad de Zaragoza.

2004-02: "Calidad institucional y factores político-culturales: un panorama inter.-nacional por niveles de renta". José Aixalá, Gema Fabro y Blanca Simón. Departamento de Estructura, Historia Económica y Economía Pública, Universidad de Zaragoza. 
2004-03: "La utilización de las nuevas tecnologías en la contratación pública". José Mª Gimeno Feliú. Departamento de Derecho Público, Universidad de Zaragoza.

2004-04: "Valoración económica y financiera de los trasvases previstos en el Plan Hidrológico Nacional español". Pedro Arrojo Agudo. Departamento de Análisis Económico, Universidad de Zaragoza. Laura Sánchez Gallardo. Fundación Nueva Cultura del Agua.

2004-05: "Impacto de las tecnologías de la información en la productividad de las empresas españolas". Carmen Galve Gorriz y Ana Gargallo Castel. Departamento de Economía y Dirección de Empresas. Universidad de Zaragoza.

2004-06: "National and International Income Dispersión and Aggregate Expenditures". Carmen Fillat. Department of Applied Economics and Economic History, University of Zaragoza. Joseph Francois. Tinbergen Institute Rotterdam and Center for Economic Policy ResarchCEPR.

2004-07: "Targeted Advertising with Vertically Differentiated Products". Lola Esteban and José M. Hernández. Department of Economic Analysis. University of Zaragoza.

2004-08: "Returns to education and to experience within the EU: are there differences between wage earners and the self-employed?". Inmaculada García Mainar. Department of Economic Analysis. University of Zaragoza. Víctor M. Montuenga Gómez. Department of Business. University of La Rioja

2005-01: "E-government and the transformation of public administrations in EU countries: Beyond NPM or just a second wave of reforms?". Lourdes Torres, Vicente Pina and Sonia Royo. Department of Accounting and Finance.University of Zaragoza

2005-02: "Externalidades tecnológicas internacionales y productividad de la manufactura: un análisis sectorial". Carmen López Pueyo, Jaime Sanau y Sara Barcenilla. Departamento de Economía Aplicada. Universidad de Zaragoza.

2005-03: "Detecting Determinism Using Recurrence Quantification Analysis: Three Test Procedures". María Teresa Aparicio, Eduardo Fernández Pozo and Dulce Saura. Department of Economic Analysis. University of Zaragoza.

2005-04: "Evaluating Organizational Design Through Efficiency Values: An Application To The Spanish First Division Soccer Teams". Manuel Espitia Escuer and Lucía Isabel García Cebrián. Department of Business. University of Zaragoza.

2005-05: "From Locational Fundamentals to Increasing Returns: The Spatial Concentration of Population in Spain, 1787-2000". María Isabel Ayuda. Department of Economic Analysis. University of Zaragoza. Fernando Collantes and Vicente Pinilla. Department of Applied Economics and Economic History. University of Zaragoza.

2005-06: "Model selection strategies in a spatial context". Jesús Mur and Ana Angulo. Department of Economic Analysis. University of Zaragoza.

2005-07: "Conciertos educativos y selección académica y social del alumnado". María Jesús Mancebón Torrubia. Departamento de Estructura e Historia Económica y Economía Pública. Universidad de Zaragoza. Domingo Pérez Ximénez de Embún. Departamento de Análisis Económico. Universidad de Zaragoza.

2005-08: "Product differentiation in a mixed duopoly". Agustín Gil. Department of Economic Analysis. University of Zaragoza. 
2005-09: "Migration dynamics, growth and convergence". Gemma Larramona and Marcos Sanso. Department of Economic Analysis. University of Zaragoza.

2005-10: "Endogenous longevity, biological deterioration and economic growth". Marcos Sanso and Rosa María Aísa. Department of Economic Analysis. University of Zaragoza.

2006-01: "Good or bad? - The influence of FDI on output growth. An industry-level analysis". Carmen Fillat Castejón. Department of Applied Economics and Economic History. University of Zaragoza. Julia Woerz. The Vienna Institute for International Economic Studies and Tinbergen Institute, Erasmus University Rotterdam.

2006-02:

2006-03: "Factors explaining the rating of Microfinance Institutions". Begoña Gutiérrez Nieto and Carlos Serrano Cinca. Department of Accounting and Finance. University of Saragossa, Spain. 